\title{
Non-Pressurized Topical Spray Pharmaceutical-Methodology of Formulation Development and Quality Control Management
}

\author{
Neelam Pawar*, Pawan Jalwal \\ Department of Pharmaceutical Sciences, Baba Mastnath University, Asthal Bohar, Rohtak, Haryana, INDIA.
}

\begin{abstract}
The medicine was given to the target site with a pressurized topical spray (aerosol pharmaceutical) and a non-pressurized topical spray solution by gently pressing the spray container against the skin and initiating the spray. Formulation components consists of product concentrate (one or more pharmaceutical drugs with relevant excipient) and packaging components (valves, pump, actuator, container). After formulation process development various quality control test like spray pattern, spray content uniformity and geometry, particulate matter, droplet size distribution, microbial limit, net content, $\mathrm{pH}$, osmolarity, weight loss, leachability, viscosity, valves, actuators, diptubes, weight checking, leak test, valve discharge rate, dosage with valves, therapeutic activity, and toxicity studies to check the quality and efficacy. The benefit of Topical Spray Life Cycle Management (post-approval adjustments, 30-day supplements, annual report, Food and Drug Administration inspection and enforcement, cover letter, risk management standard and related information from the International Organization for Standardization) is that it covers the entire lifecycle of a topical spray, from conception through formulation design development to marketing. The product lifecycle management data offers regulatory bodies with a
\end{abstract}

significant financial benefit. Topical non-pressurized sprays have been developed for a variety of applications due to their ease of use, environmental friendliness, low cost, and innovative technology. This review give details about meter dose topical spray of Estradiol, 1\% tolnaftate, 2\% Miconazole nitrate spray, $0.5 \% \mathrm{w} / \mathrm{w}$ Voriconazole spray, Clotrimazole transdermal apray, Lopinavir meter dose transdermal spray are studied by researcher. This review also enlisted patents and marketed formulation on topical spray from year 2007 to 2020

Key words: Non-pressurized topical spray, Lifecycle management, Scale up and post approval changes, Quality control, Valve Components.

\section{Correspondence}

Ms. Neelam Pawar,

Department of Pharmaceutical Sciences, Baba Mastnath University, Asthal Bohar, Rohtak-124021, Haryana, INDIA.

Email id: neelampawar5555@gmail.com

DOI: 10.5530/ijpi.2021.3.46

\section{INTRODUCTION}

Sprays can be in the form of coarse droplets or eventually divided solids of aqueous or oleaginous solution that will be sprayed topically and to the nasal pharyngeal tract, and these suspensions and solutions will be poured into spraying bottles. The therapeutic agent and various types of excipients are dissolved in a suitable solvent in the pharmaceutical solution. The solution delivered the medicine to the target spot by gently pressing the spray container against the skin and activating the discharge of the spray. The medication spreads throughout the skin's surface before being absorbed. According to the literature, topical sprays contain the following ingredients: medicament, film forming, carrier, penetration enhancer, solublizer, plasticizer, and water-soluble additive. Topical spray medication compositions like antiseptics, germicides, and anaesthetics are available on the market. The spray particles delivered by topical spray are bigger than those delivered by nasal spray. When sprayed on the skin, the composition must generate a breathable, stable film across a specific surface area. ${ }^{1}$

The liquid droplets, solid particles, or carrier gas in a pressurized topical spray (aerosol pharmaceutical) are compressed or liquefied under pressure in the container. When the pressure in the container drops, the ingredient is delivered to the application place as fine solid particles and liquid mist. Value assembly, gasket, propellant, actuator, stem, spring, housing, mounting cup, and dip tube are some of the components of an aerosol spray container. ${ }^{2}$

Aim and objective of review article to provide topical spray products pharmaceutical lifecycle management data offers regulatory bodies with a significant financial benefit. Topical non-pressurized sprays have been developed for a variety of applications due to their ease of use, environmental friendliness, low cost, and innovative technology.

\section{METHODOLOGY OF MANAGEMENT OF TOPICAL SPRAY}

Design, define, development, composition, dosage form, pharmacology, indication, administration, dosage, contraindication, strength, assay, content uniformity, quality, undesirable effect, over dosage, specification, container closure system, labelling, miscellaneous changes, packaging information, and more are all aspects of topical spray lifecycle management. Topical spray drug products contain a solution of the medicine plus an excipient in a spray bottle. The active material is equally distributed across the skin's surface area by the spray bottle. The paper contains details on the chemistry, manufacturing, and documentation that should be included in a New Drug Application (NDA) or Abbreviated New Drug Application (ANDA) for a topical spray with local and systemic effects. Product lifecycle management has enabled products to be quickly sold with minimal development costs and excellent regulatory compliance in today's world. ${ }^{3}$

\section{Formulation Components}

The product concentration, which is the active medication, is coupled with extra excipient in the spray formulation. Each formulation component should be identified by the name given by the International Union of

This is an open access article distributed under the terms of the Creative Commons Attribution-NonCommercial-ShareAlike 4.0 License, which allows others to remix, tweak, and build upon the work non-commercially, as long as the author is credited and the new creations are licensed under the identical terms. 
Pure and Applied Chemistry (IUPAC), together with the structural formula and molecular weight. If any other mixtures or proprietary preparations are used as formulation components, they must be thoroughly documented, including their identities and entire composition statements. ${ }^{4}$

\section{Product Concentrates}

A product concentrate consists of one or more (in combination) pharmaceuticals together with other relevant excipients such as solvent, co-solvent, volatile solvent, non volatile vehicle, film forming polymers, penetration enhancer, solublizers, plasticizers, and humectants.

The formulation of topical spray, according to US Patent No. 4,534,958, includes propellant, volatile solvent, water, and polyoxyethylene copolymer. The following definitions are related to topical spray technology and are described in US Patent 6,962,691 B1. The term "topically active" refers to a drug or medication that must be applied topically to the therapy. To dissolve the medicine into the formulation, a 'solubilizer' is introduced. Polymers of acrylate and methacrylic ester, polyhydric alcohol, Vitamin E, labrasol, and surfactants are included. Through talents performed to the skin, 'Percutaneous Penetration' increased the rate of medication penetration. The medication is then circulated throughout the body. These are also known as "accelerators" or "sorption promoters." The component that forms a flexible and adhering coating on the skin is known as a "plasticizer." Polyethylene glycol, propylene glycol, castor oil, dimethyl isosorbide, and citrate esters are examples of plasticizers. Many claims about topical spray composition contained in US Patent 6962691. B1 are Trichloromonofluoro methane, methylene chloride- $27 \%$ w/w, dichlorodifluoromethane $40 \% \mathrm{w} / \mathrm{w}$, dimethyl isosorbide- $5 \% \mathrm{w} / \mathrm{w}$, ethanol-28\% w/w, acetone-27\% w/w, estradiol-1\% w/w, PVP-1\% w/w, Vitamin E-1\% w/w, PEG-6000\%. (Table 1) shows the plasticizer, solubilizer, permeation enhancer, film forms, antioxidant, and $\mathrm{pH}$ adjustant. ${ }^{5}$

\section{PACKAGING COMPONENTS}

The valves/pump, container, and actuator are all included in the packaging of non-pressurized topical spray. Containers are an important part of the pharmaceutical topical spray system. There are numerous types of containers available on the market, including glass, stainless steel, aluminium, and plastic. Transparent Polyethylene Tetraphthalate Plastic (PET) bottles with sizes ranging from $10 \mathrm{ml}$ (milli liter) to $500 \mathrm{ml}$ are available in the market and are given away based on drug compatibility. These PET plastic bottles have a $20 \mathrm{~mm}$ (milli meter) neck and are easily adaptable to any value now available on the market. The dip tube of value assembly fits in void of container so that last drop of spray can be sprayed without any problem. Spray valves emitted the content through container and also regulate flow of product concentrate through container. Valve assembly delivers an exact amount of spray at one shot. The uses of pumps assist us to deliver propellant free delivery. Pumps volume is series from $0.2 \mathrm{ml}$ to $1 \mathrm{ml}$ per actuation. A unique range of VP7 and VP3 are offered in market with $20 \mathrm{~mm}, 22 \mathrm{~mm}, 24 \mathrm{~mm}$ and $28 \mathrm{~mm}$ fine mist spray pump made up of polypropylene and polyethylene. The VP7 pumps resistant to hydrocarbons and they are assembling and manufactured by Aptar pharmaceuticals. Spray orifices must have exact dimensions and be composed of a variety of polypropylene or polyethylene materials. Actuators come in a variety of shapes and sizes to adjust the spray angle and height of the spray nozzle over the skin surface. The spray nozzle aligns the aperture with the skin's surface. The spray angle, height, and volume can be adjusted by adjusting the medication concentration and penetration enhancer in the mixture. Actuator VV1.1 is a component of a large sprayer that is utilized in a polypropylene spray valve with a groove width of $20 \mathrm{~mm} .^{7}$

\section{Pump Dispenser}

The spray mixture is contained in the container of the pump dispenser. The process may entail mixing components with or without a liquid propellant; however, composition spread in a pump may not necessitate the use of a propellant. The mechanism for metered dispersing of products and non-pressurized containers is a finger-actuated mechanism, either in spray or fluid form that requires mechanical energy to operate the spray pump, which is provided by actuator dispersion. The liquid in the system, on the other hand, gives energy to the aerosol valve device. Pumps are offered in dosages of 45, 50, 55, 80, 90, 100, 130, 140, and $220 \mathrm{~mm}^{3}$ for pharmaceutical applications, meeting European pharmacopoeia and FDA requirements. ${ }^{8}$

\section{Valve Component}

Valve is multifunctional, capable of being easily opened and closed, in addition, is capable of deliver content in desired form. Valve component consist of actuator, valve, stem, gaskets, mounting cups, valve spring are describe in Figure 1.

\section{FORMULATION DEVELOPMENT}

The medicine must enter into the skin or complex tissue and be chemically, physiologically, and aesthetically stable. To begin, create a target product profile and explain the desired critical characteristics. In contrast to oral and other formulations, the desired therapeutic impact comprises expected product strength or Active Pharmaceutical Ingredient (API), improved skin penetration and release from product goals, packaging, and target shelf life. A important issue to managing in topical formulation development is the development of a topical spray solution that can eliminate greasiness when rubbed on the skin. Preformulation investigations include solubility in non-aqueous solvents, lipophilic solvents, $\mathrm{pH}$ profiles, and compatibility tests, all based on the rationale for formulation design. After that, prototype formulations are created. Non-aqueous, non-volatile, volatile, and aqueous solvents are used to make a topical solution in which the medication and polymer dissolve. Permeation enhancers can also be added to the formulation or incorporated into the polymeric solvent system. The medicine was weighed in a glass bottle and the weight was altered using a solvent. The total weight was adjusted such that the right amount of medicine was released from the system to provide a therapeutic effect at the application site. ${ }^{9}$

\section{QUALITY CONTROL OF TOPICAL SPRAY}

\section{Pump Delivery}

Pump to pump delivery should be tested in terms of medicinal product content. Pump assembly should meet the approval criteria, as determined by the pump manufacturer's precise dimensions and by the applicant's weight of spray pump delivery. Individual spray content must be within $15 \%$ (percentage) of the filled container weight, while mean weight must be within $10 \%$ of the filled container weight. Acceptance requirements for small dosage pumps (e.g. 20 microlitre) must be included in the drug product specification. ${ }^{10}$

\section{Spray Content Uniformity Limits}

The active component value should be between 80 and 120 percent in 10 containers per spray, with no more than 2 of 20 configurations from start to end exceeding this restriction. Each spray's active constituent should be between 70 and 125 percent, and the mean value of the active ingredient per spray should be between 85 and 115 percent. If there are 20 sprays, 3 to 6 actuation without exceeding 80 to 120 percent of the label, and definition of activation and end not exceeding 85 to 115 percent of the label. The active ingredient value should not be less than 
Table 1: Shows Non-pressurized Topical Spray Product Concentrate. ${ }^{6}$

\begin{tabular}{|c|c|c|c|}
\hline S. No. & Composition & Use & Example \\
\hline 1 & Plasticizers & Form flexible and adherent film on skin surface & $\begin{array}{ll}\text { - } & \text { Citric Esters } \\
\text { - } & \text { Dimethyl Isorbide } \\
\text { - } & \text { Polyethyl Glycole } \\
\text { - } & \text { Propylene Glycol } \\
\text { - } & \text { Castor Oil } \\
\text { Glycerol }\end{array}$ \\
\hline 2 & Penetration Enhancer & $\begin{array}{l}\text { Open tight junction, increase the drug absorption } \\
\text { through decrease barrier resistance }\end{array}$ & $\begin{array}{ll}\text { - } & \text { Lipophilic Solvent Dimethyl Sulfoxide } \\
\text { - } & \text { Surfactant-Tweens } \\
\text { - } & \text { Menthol } \\
\text { - } & \text { Oleic Acid } \\
\text { - } & \text { Mixed Esters of Capric and Caprylic Acid }\end{array}$ \\
\hline 3 & Film Forming Polymers & Stable film on skin surface & $\begin{array}{ll}\text { - } & \text { Acrylic Polymer or Copolymer } \\
\text { - } & \text { Metha Acrylic Polymer } \\
\text { - } & \text { Copolymer of Dimethylamine Ethyl Methacrylate } \\
\text { - } & \text { Polyvinyl Acetate } \\
\text { - } & \text { Cellulose Acetate } \\
\text { - } & \text { Polyvinyl Alcohol } \\
\text { - } & \text { Ethyl Cellulose } \\
\text { - } & \text { Hydroxy Methyl Cellulose }\end{array}$ \\
\hline 4 & Solubilizer & $\begin{array}{l}\text { Dissolve or dispersement of medicament in } \\
\text { formulation }\end{array}$ & $\begin{array}{ll}\text { - } & \text { Polyhydric Alcohol } \\
\text { - } & \text { Vitamin E } \\
\text { - } & \text { Labrosol } \\
\text { - } & \text { Acrylate and Methacrylate Ester Polymer } \\
& \text { Polyethylene Glycol } 400 \\
\text { - } & \text { Fatty Acid }\end{array}$ \\
\hline 5 & Humectants & Reduce the loss of moisture & $\begin{array}{ll}\text { - } & \text { Polyhydric Alcohol } \\
\text { - } & \text { Polyvinyl Pyrrolidone } \\
\text { - } & \text { Propylene Glycol } \\
\text { - } & \text { Butylene Glycol } \\
\text { - } & \text { Sorbitol }\end{array}$ \\
\hline 6 & Non-Aqueous Vehicle & Use to increase the solubility of drug & $\begin{array}{ll}\text { - } & \text { Acetone } \\
\text { - } & \text { Isopropyl Alcohol } \\
\text { - } & \text { Methyl Ethyl Ketone } \\
\text { - } & \text { Methylene Chloride } \\
\text { - } & \text { Ethyl Acetate } \\
\text { - } & \text { Methylene Dimethyl Ether }\end{array}$ \\
\hline 7 & Aqueous Vehicle & Use to increase the solubility of drug & $\begin{array}{ll}\text { - } & \text { Sodium Lauryl Sulphate } \\
\text { - } & \text { Polaxomers } \\
\text { - } & \text { Polyoxyl } 40 \text { Hydrogenated Castor Oil } \\
\text { - } & \text { Polyethylene Glycol }\end{array}$ \\
\hline 8 & Antioxidants & Prevent oxidation of API & $\begin{array}{ll}\text { - } & \text { Butylated Hydroxy Toluene } \\
\text { - } & \text { Sodium Metabisulfite } \\
\text { - } & \text { Ascorbyl Palmitate } \\
\text { - } & \text { Btylated Hydroxy Anisole } \\
\text { - } & \text { Cysteine Hydrochloride } \\
\text { - } & \text { Tocopherol } \\
\text { - } & \text { Propyl Gallate }\end{array}$ \\
\hline 9 & pH Adjusting Agents & Maintain $\mathrm{pH}$ & $\begin{array}{ll}\text { - } & \text { Sodium Hydroxide } \\
\text { - } & \text { Tromethamine } \\
\text { - } & \text { Hydrochloride Acid }\end{array}$ \\
\hline
\end{tabular}




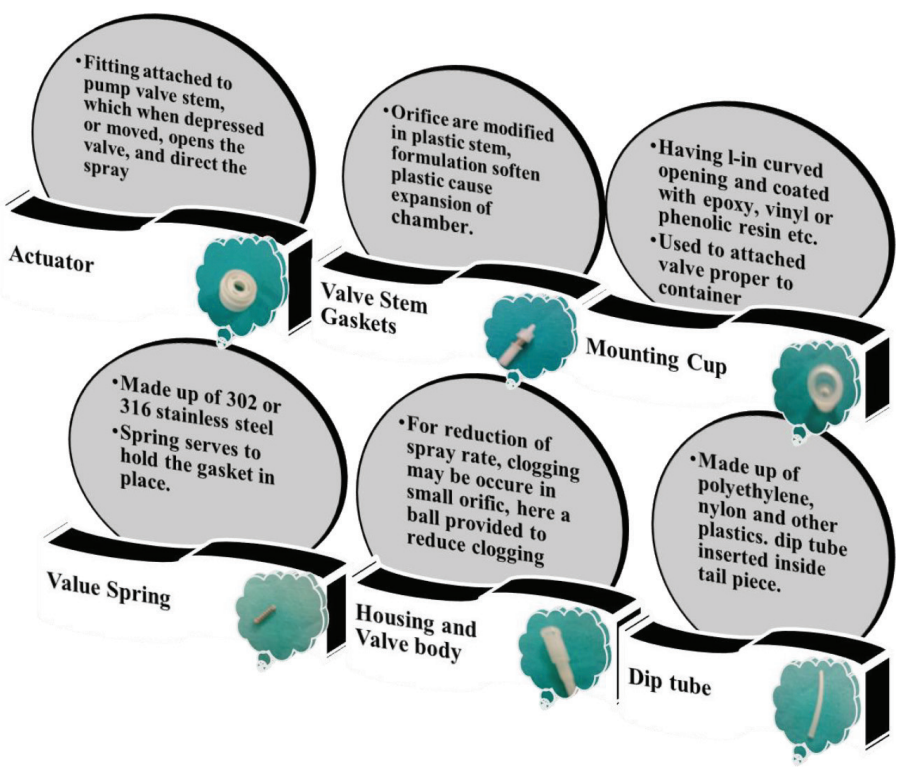

Figure 1: Showing the valve component.

80 to 120 percent, and the total medication content should be limited to 85 to 115 percent of label claims with 20 extra containers for 6 actuations. ${ }^{11}$

\section{Geometry and Spray Pattern}

Spray pattern and geometry are determined by the formulation, measuring chamber size, nozzle size and shape, and pump design. Where the spray geometry is not regularly reviewed, the spray pattern should be checked on a regular basis. ${ }^{12}$

\section{Size Distribution of Droplets}

Droplet size distribution for laser diffraction method can be adjusted in terms of D10, D50, and D90, and should be set with experimental and instrumental circumstances. The droplet size should be provided in the test circumstances, and the $\mathrm{D}_{10}, \mathrm{D}_{50}$, and $\mathrm{D}_{90}$ values should be calculated using the laser diffraction laser distribution method. ${ }^{13}$

$$
\text { Span }=\frac{D_{90}-D_{10}}{D_{50}}
$$

\section{Size Distribution of Particles}

Various semi-quantitative and qualitative methods can be employed to analyze the drug particle distribution, including changes in drug substance particle morphology, crystal development, the existence of bigger particles, and the amount of agglomerates. ${ }^{14}$

\section{Particulate Matter}

Validated test and acceptance criteria are always present in the product. Particulate matter levels vary throughout the manufacturing process, including the formulation, container, and closing system. ${ }^{15}$

\section{Net Content Weight Loss, Microbial Limit (Stability)}

The United States Pharmacopeia (USP) 61> specifies microbial test limits. The minimal fills for the net content test for spray prescribed in USP 755. The weight loss test for container and closure sealing characteristics in upright and horizontal or upright and inverted positions.
pH, Osmolality, Leachability, and Viscosity are all terms that are used to describe the properties of a substance. As per the approval criteria, the spray formulation shall be evaluated for $\mathrm{pH}$, osmolality, leachability, and viscosity. If the formulation contains osmolality and viscosity, the protocol and acceptability criteria must be followed. ${ }^{16}$

\section{Dip-tubes, Valves, Actuator}

The 'Committee' of the Industrial Pharmaceutical Technical Section' Academy of Pharmaceutical Sciences devised topical spraying methods to determine the size of valve delivery and consistency of actuation between each valve delivery. Valve approval criterion will be 54 litres or below (15\%) and 55 to 200 litres (10\%). Valves are rejected if four or more of the fifty submissions do not meet the criteria. If three submissions exceed the limit, the valve should be checked again for another 25 deliveries. If one delivery exceeds the limit, the lot is disqualified. Take 25 valves and place them on the containers. Test solution is then filled in container with 0.020 -inch orifice' actuator. Valve delivery per actuation at $\mu \mathrm{L}=$ Individual delivery in $\mathrm{mg} /$ Specific gravity of the test solution. ${ }^{17}$

\section{Checking Weight}

Weight checking is performed by filling an empty non-pressurized container to the filling lines, then removing the concentration and weighing it. ${ }^{18}$

\section{Test for Leakage}

Determine the size of the crimp and examine it to do a leak test. Transferring the full containers into a water bath provided an absolute check of the valve. ${ }^{19}$

\section{Testing of Sprays}

Pure concentration should be transparent in the dip tube. Defects in valves and spray pattern were discovered. ${ }^{20}$

\section{Rate of Valve Discharge}

For a period of time, the identified weight product is sprayed. Change the container's weight to $\mathrm{gm} / \mathrm{sec}$ at the time of release by re-measuring it. ${ }^{21}$

\section{Valves and Dosage}

Repeat for the volume established by the test, moving a specified amount after determining the exact weight of the container. Containers were reassembled and sorted, and the difference in intravenous weight was divided by the number of dosage forms, yielding an average dose. ${ }^{22}$

\section{Therapeutic Effects}

The therapeutic activity of a topical spray sprayed on test sites to determine drug content adsorption is determined. ${ }^{23}$

\section{Toxicity Research}

Irritation and chilling effects are determined for topical spray. Design, define, development, composition, dosage form, pharmacology, indication, administration, dosage, contraindication, strength, assay, content uniformity, quality, undesirable effect, over dosage, specification, container closure system, labelling, miscellaneous changes, packaging information, and more are all aspects of topical spray lifecycle management. ${ }^{24}$ Quality control test for topical non-pressurized topical spray are given below in Figure 2 .

\section{DEVELOPMENT PHASE APT}

\section{Changes in Level}

Level 1: These modifications have resulted in a notable change in the formulation. 


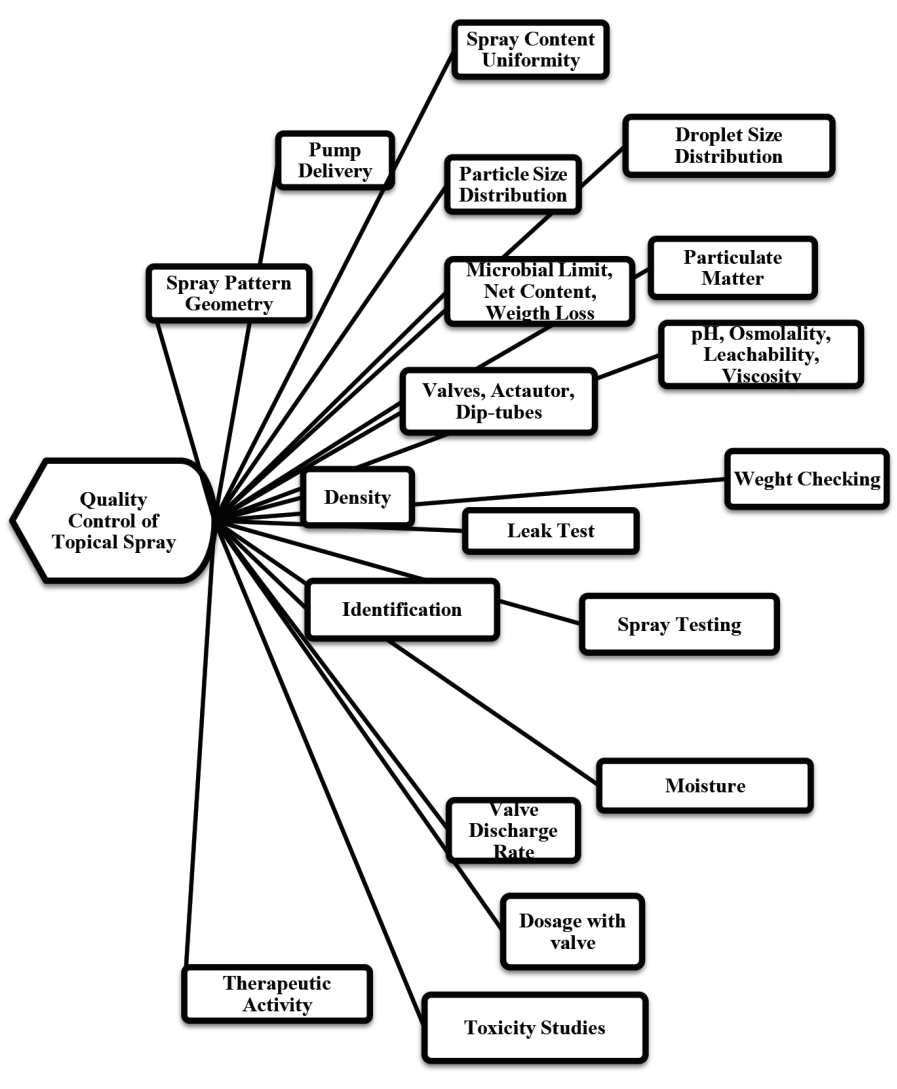

Figure 2: Quality control test for topical non-pressurized topical spray.

Level 2: These modifications have a significant impact on the formulation value and performance.

Level 3: These adjustments have a moderate impact on formulation quality.

\section{Supplements Containing CBE-30}

Changes that will be implemented in 30 days must be submitted to the FDA (Food and Drug Administration) 30 days prior to the drug's marketing approval. It has two types of moderate modifications: moderate changes 30 days before handling of the drug product submitted to the FDA and moderate changes 30 days after handling of the drug product submitted to the FDA. If any information is missing, FDA will send a supplement notice to the application within 30 days, and these supplements will need to be changed and labelled as "change being effected." If the FDA approves these revisions, the drug's distribution can be halted. ${ }^{25}$

\section{Report on the Previous Year}

Clinical efficacy, clinical safety, pharmacology, and toxicology are included in the annual report's summary section, as well as accelerated studies, paediatric studies and post-marketing studies (i.e. clinical efficacy, clinical safety, pharmacology, and toxicology). Annual progress reports should be sent using FDA-2252 as the transmittal form. After the application of a spray product has been approved, the applicant has 60 days to submit an annual status report. Two copies of distributed drug product articles, a report to the FDA district office, bacteriological contamination, deterioration in distributed product, and cover letter that includes the phrase "NDA-Field Alert Report" should all be sent to the Center for Biologics Evaluation and the Research Centre for Drug Evaluation and Research. ${ }^{26}$

\section{Rejection and Comeback}

From manufacturing operations, a certain quantity of drug product might be residue and recovered. We can reuse such materials if they can be recycled. After the approval of the quality control head, such material can be reused. $5-10 \%$ of the total amount of the following batch's residue can be added, and the batch's stability or life period should be determined. If the usual life span is reduced as a result of the addition of residue information, it must be stored in packing and labelling instructions. ${ }^{27}$

\section{Recall of the Market}

The FDA categorizes market recalls into three categories: I, II, and III. When a spray product has the potential to have a major negative impact on one's health and even mortality, it is classified as class I. The circumstance in which the spray product does not produce temporary health repercussions is classified as class II. In class III spray medication products, there are no negative health effects. For the consumer level, a class I recall should be completed in 12 to $24 \mathrm{hr}$, a class II recall in $24 \mathrm{hr}$, and a class III recall in 3 days. Market withdrawal is the removal of a distributed product from the market as a result of noncompliance, and it should not be susceptible to FDA legal action.

\section{Inspection and Enforcement by the FDA}

After the inspection is completed, the FDA summarizes the report, stating that the entire medication composition should be in compliance with Section 503A and Federal Law. Following the inspection, a post-inspection assessment confirms that all manufacturing and production facilities meet cGMP (Current Good Manufacturing Practice) regulations. FDA was providing input to states and other stakeholders, which included observations that showed deviations (Forms FDA 483). Exemption from cGMP requirements under Section 503A discharge. Compounders are targeted for distributing prescription items across state lines that have the potential to adversely influence a significant number of patients. FDA expects to schedule a review of compounders with multiple out-of-state licences who have been subject to the disciplinary action stated above in the near future. The FDA has noticed that it is in charge of the most convenient oversight of outsourcing facilities. Our goal is to gradually increase the frequency of outsourcing facility inspections while reducing the time between inspections and subsequent FDA actions. Before beginning the audit, obtain FDA Form 482 from the appropriate authority. ${ }^{28}$

\section{Letter of Caution}

Pharmaceutical businesses are required by the FDA and the European Medicines Agency (EMA) to receive Current Good Manufacturing Practice (cGMP) complaints. If FDA inspectors look into any breaches committed with this device (FDA Form 483). If the FDA believes the breach of GMP is serious or the response letter is inadequate, it may issue a warning letter to the company. Nutra Pharma received a warning letter from the FDA for their product "Nyloxin Spray." 2000-05-08 ScheringPlough Corporation "Analysts are instructed to remove bottle spraying tips and wash with methanol before re-testing in the operation of the uniformity of Spray Content Assays, however this step is not mentioned in the documented methods." Furthermore, the test results are calculated and used to replace the first findings report's Out of Specification (OOS) results. ${ }^{29}$

\section{Corrective Actions}

When you get Form 483, the FDA expects you to investigate the infraction as soon as possible. You cannot let authorities down merely by hinting that you are prepared to act. The maker should take sufficient steps to resolve the disagreement. Warning letters should be taken seriously, as 
some may have more significant ramifications than others. If the FDA alerts you about false advertising, you can easily remedy the problem by ignoring it. ${ }^{30}$

\section{Seizure}

Even if it does not include products that are not at danger of contamination due to their packaging (e.g. food in cans) or the location, a mass seizure of products in a dirty or filthy storage is considered a mass seizure (e.g. product preserved in a freezer or on a floor where no chance of insect a rodent invasion). Even if it does not include products that are not at risk of contamination due to their packaging (e.g. food in cans) or the location, a mass seizure of products in a dirty or filthy storage is deemed to be a mass seizure (e.g. product preserved in a freezer or on a floor where no chance of insect a rodent invasion). Section 304 (a) of the United States Code prohibits the seizure of similar goods in several District Courts. The office of enforcement and important operations (OEIO), division of enforcement, has a multi-seizure misbranded product enforcement plan. From the time the investigator reports the disputing conditions until the seizures are completed, relevant events and proofs usually alter. The Department of Justice (DOJ) plays a critical role in affecting seizures while evidence or proof is still fresh, ensuring that the setting order in which the commodities are prepared or held (21 U.S.C. 342(a) (4)) is accurately reflected. The evidence should show that the invasion resulted in widespread 342 (a)(4) contamination or that the live animals were contaminated. ${ }^{31}$

\section{Injunctions}

These are court orders that require something or someone to stop doing something, such as selling tainted food or producing a drug or equipment that does not comply with FDA rules. An FDA injunction is a powerful enforcement weapon because it can protect a company by prohibiting the sale of its products. Embargo or seizure guidelines are variants on injunctions that allow specific products to be taken off the market. The goods is kept safe in the firm warehouse, or it could be seized and impounded by the government. If the product has a short shelf life, such as a brilliant paint or a drug with a short expiration date, the company must comply with whatever restrictions the agency imposes, because delaying the order will render the product useless. ${ }^{32}$ Figure 3 depicts the methods for Life Cycle Management of Topical Spray.

\section{PUBLICATION OF RESEARCH}

The metered-dose transdermal spray of estradiol for the treatment of acute climacteric syndrome was examined and evaluated by Fait T et al. $2018 .^{33}$ Shellow W 2018 studied on 46 patients with acute tinea pedis were treated with either $1 \%$ tolnaftate aerosol spray powder or $2 \%$ miconazole nitrate aerosol spray powder. ${ }^{34}$ Ishwar NP et al. 2017 created a new spray including an antiacne chemical as well as a propane, butane, and LPG mixture. ${ }^{13}$ For fungal infection, Mori NM et al. 2017 developed a 0.5 percent $\mathrm{w} / \mathrm{w}$ voriconazole transdermal spray. ${ }^{35}$ Sritharadol $\mathrm{R}$ et al. 2017 created mupirocin sprays to create a film composition with the best physicochemical and mechanical qualities. ${ }^{1}$ Antimicrobial sulphadiazine creams or ointments were tested in the treatment of third-degree burns (Bhadra $S$ et al. 2016). ${ }^{36}$ Glycerin nanocapsules and nanoemulsions of Ginko biloba GKB have been examined to confirm the antifungal and antibacterial activities (Ahmed $\mathrm{AH}$ et al. 2016). ${ }^{3}$ The investigated transdermal spray (Mandal UK et al. 2016) has numerous advantages over gel, ointment, and acne easy availability, dosage flexibility, reduced visible skin irritation, and rapid drying rate on application site due to the volatile solvent used. ${ }^{7}$ Paradkar P et al. 2015 developed a clotrimazole transdermal spray that can deliver the medicine for up to $12 \mathrm{hr}$ and is antifungal. ${ }^{37}$ Lopinavir metered-dose transdermal spray is being developed by Patel D et al. 2015 to improve skin permeability. ${ }^{38}$ Hormone transdermal spray was examined by Algin-Yapar E et al. 2014. ${ }^{39}$ Desai C

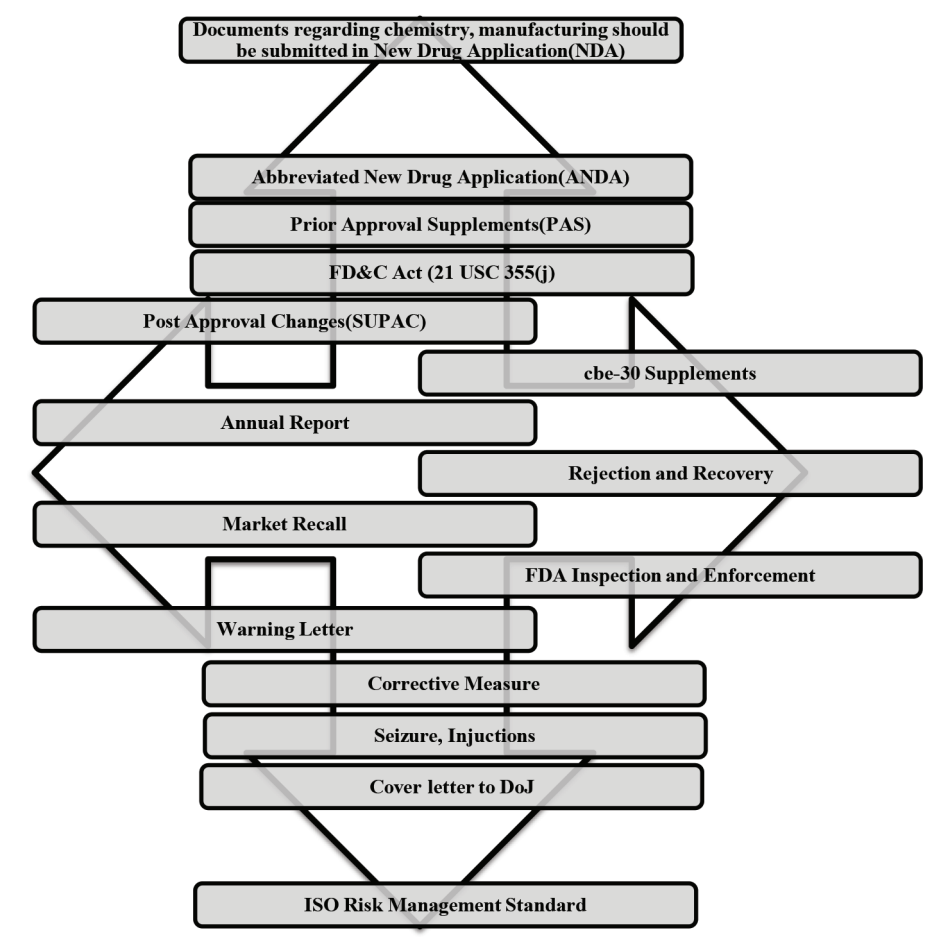

Figure 3: The methodology of Life Cycle Management of Non-pressurized Topical Spray.

et al. 2014 evaluated 29 patients for split skin craft surgery in randomised double-blind trials. ${ }^{40}$ The effect of matrix assembly and drug production on human skin is investigated by Monica L et al. $2013 .{ }^{9}$

\section{PATENTS}

The spray composition indicated in Table 2 is covered by a number of patents.

\section{Marketed Formulation}

Marketed formulation (Medicines.org.uk) ${ }^{50}$ of topical spray listed in Table 3.

\section{DISCUSSION}

As the study implies, non-pressurized topical sprays do not contain any kind of propellant. These formulations are more user-friendly, reduce formulation costs because propellant is expensive, are ecologically friendly, easy to apply, and add to patient comfort. The spray pump, which uses mechanical energy provided by the triggering actuator, is used to dispense the formulation. ${ }^{33}$ Formulation delivery is dependent on value assembly with cap and mechanical energy. Without contaminating the entire product, the benefits of non-pressurized topical spray can be offered. Medicines can be administered directly to the desired action site in the appropriate form, such as a spray or a foam with a narrow area of coverage. It avoids the digestive tract's first-pass metabolism. The ability to administer medications to a specified location selectively. ${ }^{5}$

Important properties of the drug substance used in spray form should be included in the application, such as particle size distribution, density, polymorphs, amorphous forms, solvates and hydrates, particle morphology, moisture and residual solvent content, solubility profile, dissociation constant, microbial quality, and specific rotation, but should not be limited to these only. The purity and impurity profile of the drug material must be determined. A $10 \mathrm{~g}$ microbial limit test is recommended. For NDA and ANDA, the International Council on Harmonization (ICH) Q3A(R) 
Pawar and Jalwal.: Non-pressurized Topical Spray Pharmaceutical

Table 2: Patents List on Topical Spray.

\begin{tabular}{|c|c|c|c|c|}
\hline S. No. & Reference & Patent & Title & Summary of invention \\
\hline 1. & Silver et al. 2007 & US2007/0231271 A1 & $\begin{array}{l}\text { For treatment of epithelial } \\
\text { lesion biocellulose as spray, } \\
\text { gel or aerosol. }\end{array}$ & $\begin{array}{l}\text { Biocellulose paste (1-50\%), hydroxyethylcellulose natrosol } \\
(0.5-4 \%) \text {, and propylene glycol are used in the formulation } \\
\text { (20-29 percent). }{ }^{41}\end{array}$ \\
\hline 2. & Charles et al. 2008 & US2008/0107758 A1 & $\begin{array}{l}\text { Topical steroid spray with } \\
\text { botanic seed oils. }\end{array}$ & $\begin{array}{l}\text { A blend of black cumin seed oil, black raspberry seed } \\
\text { oil, and red raspberry seed oil made using the cold press } \\
\text { method was used in a pharmaceutical topical spray } \\
\text { composition containing corticosteroid, an alcohol, a } \\
\text { propellant, and botanic seed oils. }{ }^{42}\end{array}$ \\
\hline 3. & Amancha et al. 2016 & WO 2015/070049 Al & $\begin{array}{l}\text { Sildenafil Sublingual Spray } \\
\text { Formulation }\end{array}$ & $\begin{array}{l}\text { Sublingual formulations including buprenorphine and } \\
\text { naloxone, as well as pharmaceutically acceptable salts and } \\
\text { derivatives, were created. }{ }^{43}\end{array}$ \\
\hline 4. & Vangara et al. 2018 & WO2016007446A1 & Diclofenac sublingual spray & $\begin{array}{l}\text { Spray of diclofenac for treatment of pain and } \\
\text { inflammation. }{ }^{4}\end{array}$ \\
\hline 5. & Rana et al. 2017 & US 2018 / 0028766 A1 & $\begin{array}{c}\text { Touch - Free Topical Spray of } \\
\text { Halobetasol }\end{array}$ & $\begin{array}{l}\text { For the treatment of skin disease, a propellant-free topical } \\
\text { spray containing halobetasol, a non-aqueous solvent, and } \\
\text { an emollient. }\end{array}$ \\
\hline 6. & Lalatendu et al. 2018 & WO2018/11/6190Al & $\begin{array}{l}\text { Topical Sprayable } \\
\text { Composition of Ketorolac } \\
\text { Tromethamine }\end{array}$ & $\begin{array}{l}\text { Topical sprayable ketorolac tromethamine formulations } \\
\text { with one or more solvents, a penetration enhancer, and a } \\
\text { buffering agent were developed for the treatment of acute } \\
\text { pain in affected joints and surrounding tissues such as } \\
\text { tendons, muscles, and ligaments. }{ }^{46}\end{array}$ \\
\hline 7. & Gerber et al. 2018 & US20190008815A1 & $\begin{array}{l}\text { Sprayable aqueous } \\
\text { composition comprising } \\
\text { glyceryl trinitrate }\end{array}$ & $\begin{array}{c}\text { Glyceryl trinitrate }(0.15-3 \% \mathrm{w} / \mathrm{w}) \text { is present in the } \\
\text { formulation. (b) water }(40-95 \text { percent by weight })(\mathrm{d}) \\
\text { ethanol }(5 \text { to } 20 \text { percent } \mathrm{w} / \mathrm{w})(\mathrm{c}) \text { water soluble polymer }(2 \\
\text { to } 10 \% \mathrm{w} / \mathrm{w}) .^{47}\end{array}$ \\
\hline 8. & Davis 2019 & US $10,463,078$ B2 & $\begin{array}{l}\text { Aerosol Delivery Device with } \\
\text { vaporization } \\
\text { (Condensing and Non- } \\
\text { condensing) }\end{array}$ & $\begin{array}{l}\text { The functional unit for condensing and non-condensing } \\
\text { vaporisation in an aerosol delivery device. }{ }^{48}\end{array}$ \\
\hline 9. & Ubaidulla et al. 2020 & WO 2006102004 & $\begin{array}{l}\text { Topical formulations } \\
\text { comprising a steroid }\end{array}$ & $\begin{array}{l}\text { Topical spray without propellant for the treatment of skin } \\
\text { diseases such as dermatoses, psoriasis, and others. }{ }^{49}\end{array}$ \\
\hline
\end{tabular}

provides recommendations on impurity in novel drug substances. FDA recommendations for submitting supporting documentation in drug applications for drug substance manufacture include information on drug substance, manufacturing, and control documents. ${ }^{10}$

The amount of medication product, as well as the composition of unit formula per container and per spray, should be included in the final formulation composition. In both unit and batch formulas, ingredient overage should be preserved and justified. In terms of physical stability and drug product performance qualities, the spray formulation is critical. Each manufacturing operation, processing, responsibility, packing, and stability testing should be listed or included in the manufacturing drug material. To control process factors and improve medicinal product quality consistency, include time, temperature, and mixing speed. ${ }^{27}$ The amount of delivered volume and formulation overfilled per container should be justified. Controls that are crucial, such as osmolality, $\mathrm{pH}$, assay, viscosity, sealing quality, and uniformity of filling, should be described. ${ }^{16}$

The benefit of Topical Spray Life Cycle Management is that it covers the entire lifecycle of a topical spray, from conception through formulation design development to marketing. Based on the data about contributing the pharmaceutical product information resolution and process, it delivers a long-term value to pharmaceutical companies. The product lifecycle management data offers regulatory bodies with a significant financial benefit. Product life cycle reduces the time it takes to bring a topical spray product to market, improves the quality of the product, and provides a framework for topical spray optimizations by reusing original data. ${ }^{18}$

Prior Approval Supplements (PAS) are a method of product lifecycle management for topical sprays in which an applicant must submit a prior approval supplement to the Food and Drug Administration (FDA) under section $505(\mathrm{~J})$ of the Federal Food, Drug, and Cosmetic Act (FD\&C) act (21 U.S.C. 355). (J). This clarifies the generic medication user charge in relation to the PAS submissions performance target and procedures. $^{22}$

Change can be completed after approval of the composition, equipment, process, and site alteration. Changes can be made to the chemistry of a drug product, its manufacturing development, and its shelf life. Many alterations can affect a drug's quality attribute, necessitating a thorough assessment of the change's impact on the final product. SUPAC-IR immediate release advice was produced by the FDA, and it describes the level of changes, feelings, and tests. ${ }^{24}$ 
Table 3: Marketed preparation of pressurized topical spray (www.medicines.org)

\begin{tabular}{|c|c|c|c|}
\hline Sr. No. & Brand Name & Drug & Manufacturer \\
\hline 1. & Symbicort & $\begin{array}{l}\text { Budesonide, } \\
\text { Formoterol fumarat }\end{array}$ & Astra Zeneca pharmaceutical, England, UK \\
\hline 3. & Aerospan HFA & Flunisolide & Mylan Specility L.P, Canonsburg, PA 15317, United States \\
\hline 4. & Breo Ellipta & $\begin{array}{l}\text { Fluticasone furoate, Vilanterol } \\
\text { trifenatate }\end{array}$ & $\begin{array}{l}\text { Glaxo Smith Kline, } 980 \text { Great West Road, Brentford, Middlesex TW8 9GS, } \\
\text { UK }\end{array}$ \\
\hline 6. & Perforomist & Formoterol fumarate & Mylan Specility L.P, Canonsburg, PA 15317, United States \\
\hline 7. & Proventil HFA & Albuterol sulfate & Merck and \& co. Imt., Galloping Hill RoadKenilworth, NJ 07033 U.S.A \\
\hline 8. & Ventolin HFA & Albuterol sulfate & $\begin{array}{l}\text { Glaxo Smith Kline, } 980 \text { Great West Road, Brentford, Middlesex TW8 9GS, } \\
\text { UK }\end{array}$ \\
\hline 11. & Duoneb & $\begin{array}{l}\text { Albuterol sulfate, Ipratropium } \\
\text { bromide }\end{array}$ & Mylan Specility L.P, Canonsburg, PA 15317, United States \\
\hline 12. & Brovana & Arformoterol tartrate & Sunovion Pharmaceutical, Marlborough, MA 01752, United States \\
\hline 13. & Canesten Dermatological Spray & Clotrimazole & Bayer plc, South Oak Way Green Park, Reading Berkshire, RG2 6AD, UK \\
\hline 14. & Ear Calm Spray & Acetic acid & Teva UK Limited, Castleford, West Yorkshire WF10 5HX, UK \\
\hline 15. & $\begin{array}{l}\text { Fostair } 100 / 6 \text { micrograms per } \\
\text { actuation pressurised inhalation } \\
\text { solution. }\end{array}$ & $\begin{array}{l}\text { Beclometasone dipropionate, } \\
\text { Formoterol fumarate dihydrate }\end{array}$ & Chiesi Limited, Manchester, Greater Manchester M22 5LG, UK \\
\hline 16. & Germoloids $^{\circ}$ HC Spray & $\begin{array}{c}\text { Hydrocortisone } \\
\text { Lidocaine hydrochloride }\end{array}$ & Bayer plc, South Oak Way Green Park, Reading Berkshire, RG2 6AD, UK \\
\hline 21. & Perianal Cutaneous Spray & $\begin{array}{l}\text { Hydrocortisone, Lidocaine } \\
\text { Hydrochloride }\end{array}$ & $\begin{array}{c}\text { Dermal Laboratories Limited, Tatmore Place Preston Road, Hitchin, } \\
\text { Hertfordshire SG4 7QR }\end{array}$ \\
\hline 22. & Canesten AF Dual Action Spray & Clotrimazole & Bayer plc, South Oak Way Green Park, Reading Berkshire, RG2 6AD, UK \\
\hline 23. & $\begin{array}{l}\text { Cutaneous Spray Savlon First Aid } \\
\text { Wash } 0.5 \% \text { w/v Cutaneous Spray }\end{array}$ & Etrimide & Novartis Consumer Health, 230 Park Avenue, 21st Floor, NY \\
\hline 24. & Ibuleve Speed Relief 5\% Spray & Ibuprofen & $\begin{array}{l}\text { Diomed Developments Limited, Tatmore Place Gosmore Hitchin Herts } \\
\text { SG4 7QR, UK }\end{array}$ \\
\hline 25. & Lamisil AT 1\% Spray & Terbinafine Hydrochloride & Novartis Consumer Health, 230 Park Avenue, $21^{\text {st }}$ Floor New York, NY \\
\hline
\end{tabular}

\section{CONCLUSION}

Topical spray medication compositions like antiseptics, germicides, and anaesthetics are available on the market. The spray particles delivered by topical spray are bigger than those delivered by nasal spray. When sprayed on the skin, the composition must generate a breathable, stable film across a specific surface area. The topical spray product has made a huge difference in the daily lives of patients with a variety of disorders. When applied to the skin by touching it, it might cause inflammation and subsequent infections. In this article, we will look at the methodology for managing the life cycle of topical sprays. Topical spray provides benefits over gel, patches and ointment such as avoidance of skin irritation, improve patient compliance and improve flux of drug into skin. So, the goal of this review article is to familiarize the readers about the formulation aspects of topical spray under the purview of latest developments in this field.

\section{ACKNOWLEDGEMENT}

Author would like to gratefully acknowledge the help of Dr. Pawan Jalwal for his invaluable review and suggestions on the manuscript.

\section{CONFLICT OF INTEREST}

The authors declare that they have no competing interests. 


\section{ABBREVIATIONS}

SUPAC: Scale-Up and Post-Approval Changes; CBE-30: Changes Being Effected-30; FDA: Food and Drug Administration; ISO: International Organization for Standardization; NDA: New Drug Application; ANDA: Abbreviated New Drug Application; PAS: Prior Approval Supplement; US: United State; ICH: International Conference of Harmonization; PET: Polyethylene Terephthalate; cGMP: Current Good Manufacturing Practice; EMA: European Medicine Agency; OOS: Out of Specification; OEIO: Office of Enforcement and Important Operation; COA: Certificate of Analysis; TRO: Temporary Restraining Order; OCC: Office of The Chief Counsel; USP: United State Pharmacopoeia; LPG: Liquefied Petroleum Gases; CNS: Central Nervous System; UK: United Kingdom; DOJ: Department of Justice.

\section{REFERENCES}

1. Sritharadol R, Nakpheng T, Wan Sia Heng P, Srichana T. Development of a topical mupirocin spray for antibacterial and wound-healing applications. Drug Dev Ind Pharm. 2017;43(10):1715-28. doi: 10.1080/03639045.2017.1339077, PMID 28581830

2. Deb PK, Abed SN, Maher H, Al-Aboudi A, Paradkar A, Bandopadhyay S. Aerosols in pharmaceutical product development. Drug Deliv Syst. 2020;2:521-77.

3. Anmed AH, Heba A. A novel topical spray formulation for Ginkgo biloba for antifungal activity. J Nanomed J Nanomed Nanotechnol. 2016;7:1-6.

4. Umar AK, Butarbutar MET, Sriwidodo S, Wathoni N. Film-forming sprays for topical drug delivery. Drug Des Dev Ther. 2020;14:2909-25. doi: 10.2147/DDDT. S256666, PMID 32884234.

5. Adhao AS, Thenge RR. Elemental impurities: a review. Res RevJ Pharm Sci. 2020;11(1):17-21.

6. Kapadia MM, Solanki ST, Parmar V, Thosar MM, Pancholi SS. Preliminary investigation tests of novel antifungal topical aerosol. J Pharm Bioallied Sci. 2012;4(Suppl 1):S74-6. doi: 10.4103/0975-7406.94145. PMID 23066214

7. Sadeq ZA, Ghazy E, Salim Z. Etodolac topical spray films, development, characterization and in-vitro evaluation. Int J Pharmacol Res. 2020;12(4):926-36.

8. Asapu U, Vobalaboina V, Yamsani M. Formulation and evaluation of novel topical Spray using naproxen as a model drug. Int J Drug Deliv. 2007;33:78-81.

9. Mounica NVN, Reddy SV, Anusha S, Evangeline L, Nagabhushanam MV, Nagarjunareddy D. Scale up and Postapproval Changes (supac) guidance for industry: a regulatory note. Int J Drug Regul. 2017;5(1):13-9.

10. Lachman L, Lieberman $\mathrm{H}$, Kanig J. The theory and practice of industrial pharmacy. 4th ed. Varghese Publication house; 1991. p. 591-96.

11. Thorat SR, Meshram SM. Formulation and product development of pressurized metered dose inhaler: an overview. Pharm Tutor. 2015;3(9):53-64

12. Ehrick JD, Shah SA, Shaw C, Kulkarni VS, Coowanitwong I, De S, Suman JD. Considerations for the development of nasal dosage forms. AAPS Advances in the Pharmaceutical Sciences Series. 2013:99-144. doi: 10.1007/978-1-46147978-9_5.

13. Pawar NI, Rajput RR, Vaghani SS, Katara BV. Formulation and evaluation of topical spray containing anti acne agent. Glob J Pure Appl Sci. 2017;05(24):14-28.

14. Warren $\mathrm{H}$, Darquenne C. Particle size distributions. J Aerosol Med Pulm Drug Deliv. 2020;33(4):1-3.

15. Merkus HG. Particle size measurement. Particle size, size distributions and shape. Part Technol S. 2009;17:13-42.

16. Ranade S, Bajaj A, Londhe V, Babul N, Kao D. Fabrication of topical metered dose film forming sprays for pain management. Eur J Pharm Sci. 2017;100:132-41. doi: 10.1016/j.ejps.2017.01.004, PMID 28069427.

17. Miller VA. FDA regulation of laboratory-developed tests. Clin Adv Hematol Oncol. 2016;14(5):305-6. PMID 27379690.

18. Farina D. Regulatory aspects of nasal and pulmonary spray drug products. Handbook of non-invasive Drug Delivery Systems. William Andrew Publishing; 2010. p. 247-90

19. Abdo RW, Saadi N, Hijazi NI, Suleiman YA. Quality control and testing evaluation of pharmaceutical aerosols. Adv Pharm Prod Dev Res. 2020:579-614

20. Le J, Schiller DS. Aerosolized delivery of antifungal agents. Curr Fungal Infect Rep. 2010;4(2):96-102. doi: 10.1007/s12281-010-0011-0, PMID 20502511.

21. Booth $\mathrm{C}, \mathrm{MM}$. Understanding container closure integrity testing. Am Pharm Rev. 2016;19(6)

22. Fitrzyk A, Niemiec K. Quality control in aerosol production. Multidiscip Aspects Prod Eng. 2018;1(1):85-91. doi: 10.2478/mape-2018-0012.
23. Khoja SS, Prajapati A, Panjwanu K, Khola S, Ahir V. Current Quality status of Indian pharmaceutical products and Statistical data on US market drug product recall by Indian pharmaceuticals. Mod Trends Pharm Educ Res. 2017.

24. Olenev E, Hamid MAA, Al-Haidri W, Lebedinskaya EA. Therapeutic aerosol: thermodynamic method for managing the aerosol particle size. Aerosol Sci Eng. 2020;4(3):219-27. doi: 10.1007/s41810-020-00069-z.

25. Apthorpe L, Hines J. Aerosol. Principles of Occupational Health and hygiene. 3rd ed. Taylor \& Francis Group; 2019. p. 54.

26. Burkhart CG. My journey of formulating a patent for topical/spray ivermectin against COVID. Open Dermatol J. 2021:15(1):34-5. doi: $10.2174 / 1874372202115010034$

27. Kumar N. Pharmaceutical market structure in India and competition concerns. Int. J. Humanit. Arts. Soc Sci. 2020;8(1):233-41.

28. Kannan S, Morais SR, Prema S, Chitra K. Auditing as a management tool in pharmaceutical companies. Int J Pharm Biol Sci. 2020;10(1):230-5.

29. Madzarevic VM. Analysis of warning letters. Clinical trials audit preparation: A Guide for Good Clinical Practice (GCP) Inspections. Wiley. 1st ed. Vol. 270; 2010.

30. McDonald K. ICH Q11: development and manufacture of drug substanceschemical and biotechnological/biological entities. GaBI J. 2012;1 (3-4):142-4. doi: 10.5639/gabii.2012.0103-4.025.

31. Trows S, Wuchner K, Spycher R, Steckel H. Analytical challenges and regulatory requirements for nasal drug products in europe and the u.s. Pharmaceutics. 2014;6(2):195-219. doi: 10.3390/pharmaceutics6020195, PMID 24732068.

32. Chavan P, Bajaj A, Parab A. Topical sprays: novel drug delivery system. J Chem Pharm Res. 2016;2(2):102-11.

33. Fait T, Fialova A, Pastor Z. The use of estradiol metered-dose transdermal spray in clinical practice. Climacteric. 2018:21(6):549-53. doi: 10.1080/ 13697137.2018.1504916, PMID 30296172

34. Shellow WV. 2\% miconazole nitrate powder in aerosol spray form: its efficacy in treating tinea pedis. J Int Med Res. 1982:10(1):28-31. doi: 10.1177/030006058201000105, PMID 7060822.

35. Mori NM, Patel P, Sheth NR, Rathod LV, Ashara KC. Fabrication and characterization of film-forming voriconazole transdermal spray for the treatment of fungal infection. Bulletin of Faculty of Pharmacy Cairo University. 2017;55(1):41-51. doi: 10.1016/j.bfopcu.2017.01.001

36. Bhadra S. Topical silver sulfadiazine retards burn wound healing in a murine model. J Am Acad Dermatol. 2015;72(5):AB273.

37. Paradkar M, Thakkar V, Soni T, Gandhi T, Gohel M. Formulation and evaluation of clotrimazole transdermal spray. Drug Dev Ind Pharm. 2015;41(10):1718-25. doi: 10.3109/03639045.2014.1002408, PMID 25579237.

38. Patel D, Kumar P,Thakkar HP. Lopinavir metered-dose transdermal spray through microporated skin: permeation enhancement to achieve therapeutic needs. J Drug Deliv Sci Technol. 2015;29:173-80. doi: 10.1016/j.jddst.2015.07.004.

39. Algin-Yapar E, Inal Ö. Transdermal spray in hormone delivery. Trop J Pharm Res. 2014;13(3):469. doi: 10.4314/tjpr.v13i3.23.

40. Desai C, Wood FM, Schug SA, Parsons RW, Fridlender CS, Sunderland VB. Effectiveness of a topical local anaesthetic spray as analgesia for dressing changes: A double-blinded randomised pilot trial comparing an emulsion with an aqueous lidocaine formulation. Burns. 2014;40(1):106-12. doi: 10.1016/j. burns.2013.05.013, PMID 23810271.

41. Silver J. Topical composition of biocellulose as gel, spray-aerosol, cream and/ or aqueous for the treatment of epithelial lesion. US Patent 0231271 A1; 2007. p. $1-5$.

42. Charles E. Topical steroid spray with botanic seed oils. US Patent 0107758 A1; 2008. p. 1-4.

43. Amancha K, Giron W, Shin H, Goskonda L. Sildenafil sublingual spray formulation. Insys Pharma, Inc. WO Patent 070049. AL; 2016.

44. Vangara K, Bockenstedt D, Yan N, Pandya R, Goskonda V. Diclofenac sublingual spray. Insys Pharma, Inc. WO Patent 2016007446A1; 2016.

45. Rana A, Keshri L, Bedi S, Kochhar R. Touch-free topical spray of halobetasol. US Patent 0028766 A 1; 2018

46. 46. Lalatendu $P$ 2018. Topical sprayable compositions of ketorolac tromethamine. Dr. Reddy's Laboratories limit. WO 2018/116190 al.

47. 47. Gerber $A$, Gorath $M$, Zimmeck T. Sprayable aqueous composition comprising glyceryl trinitrate. G POHL: BOSKAMP GMBH \& Comp KG. US Patent 20190008815A1; 2019.

48. 48. Davis M. Aerosol delivery device with condensing and Non - condensing vaporization. RAI Strategic Holdings, Inc. US Patent 10. 2019;463(078):B2.

49. 49. Ubaidulla U, Kandavilli S, Vairale AS, Wayne JA, Nalamothu V et al. Topical formulations comprising a steroid. US Patent 9364485; 2008.

50. 50.Medicines.org.uk. Summary of product characteristics (Smpc) - (Emc) [cited Mar 17 2021]. Available from: https://www.medicines.org.uk/emc/product/841/ smpc. 